\section{Germination and Morphology of Sophora secundiflora Seeds Following Scarification}

\author{
John M. Ruter ${ }^{1}$ and Dewayne L. Ingram \\ Department of Environmental Horticulture, Institute of Food and \\ Agricultural Sciences, University of Florida, Gainesville, FL 32611
}

Additional index words. propagation, scanning electron microscopy, mescal bean, woody plants

Abstract. Seeds of Sophora secundiflora (Ort.) Lag ex. DC. (mescal bean) were scarified with hot water or concentrated sulfuric acid to determine an optimal pretreatment for successful germination. Scanning electron micrographs indicated that the acid scarification treatment removed the seed cuticle. One-year-old seeds were successfully stored and germinated $\approx 2$ days sooner than from the current year if both were given an acid pretreatment. Germination rate increased as acid pretreatment time increased from 30 to 120 minutes. Soaking seeds in water at room temperature or in hot water (initially 93C) for 24 hours had no effect on germination.

Sophora secundiflora is an evergreen shrub or small tree native to western Texas, New Mexico, and northern Mexico. The genus Sophora (Papilionaceae) consists of $\approx 30$ species with world-wide distribution (Allan, 1961). Sophora secundiflora is considered an excellent native plant for landscaping purposes in Texas because of its tolerance to alkaline soils and moderate drought. The foliage is glossy dark green, and the plant produces terminal racemes of fragrant showy flowers in early spring. The plant is considered hardy in U.S. Dept. of Agriculture (USDA) zones 8 to 10 and can be used successfully for hedges, screening, mass plantings, and as a specimen tree.

Sophora secundiflora is considered difficult to root and is propagated primarily by seed (Froberg, 1985; Smith and Pittcock, 1989). The seeds are reported to be shortlived, and shipment of seed as soon as ripe without drying is recommended (Wyman, 1953). Smith and Pittcock (1989) established that mature seed of $S$. secundiflora would germinate readily, whereas old seed required acid scarification for germination. While seed germination appears to be the accepted method for propagating this species, no protocols were found regarding pretreatment to break seedcoat dormancy. Therefore, the objectives of this study were to: 1) test the viability of 1year-old seed as compared to fresh seed, 2) determine an optimal pretreatment protocol for successful scarification and germination of $S$. secundiflora seed, and 3) examine the morphological results of seed scarification.

Received for publication 16 Apr. 1990. Florida Experiment Station Series no. R-00612. We express appreciation to the IFAS Electron Microscopy Lab for their assistance. Tire cost of publishing this paper was defrayed in part by the payment of page charges. Under postal regulations, this paper therefore must be hereby marked advertisement solely to indicate this fact.

'Former Graduate Assistant. Current address: Dept. of Horticulture, Coastal Plain Experiment Station, P.O. Box 748, Tifton, GA 31793.
Seeds were collected from wild stands of $S$. secundiflora in Medina County, Texas. Seeds produced in 1987 were collected in Mar. 1988, while seeds produced in 1988 were collected in Dec. 1988. Both crops were sealed in polyethylene bags and stored at room temperature $(\approx 20 \mathrm{C})$ until Mar. 1989.

Treatments included: 1) control (distilled $\mathrm{H}_{2} \mathrm{O}$ soak for $24 \mathrm{~h}$ ), 2) initial hot water soak at $93 \mathrm{C}$, allowed to cool for $24 \mathrm{~h}$, and 3-5) sulfuric acid 30,60 , or $120 \mathrm{~min}$. Concentrated sulfuric acid $\left(18 \mathrm{~N} \mathrm{H}_{2} \mathrm{SO}_{4}\right.$ was used for treating seeds. For each treatment, seeds in the acid were gently and periodically agitated followed by a 2-h wash with distilled water at $22 \mathrm{C}$.

After treatment, 30 (1987) or 50 (1988) seeds per treatment were rolled in moist paper towels (10 seeds/replication) and placed in plastic bags for germination. Seeds were germinated in a dark germination chamber held continuously at 30C. Distilled water was added to moisten the paper towels as needed. On days $0,1,3,5,7,9,11,13,17,20$, and 27 , seeds were removed-and fresh weight, seed width, seed length, and germination were determined. A seed was considered germinated if the radicle could be seen protruding through the seedcoat. The mean number of days for germination of $50 \%$ of the seeds by day 27 was determined.

Seedcoat samples taken after each treatment for scanning electron microscopy (SEM) observation were oven-dried at $70 \mathrm{C}$ for $24 \mathrm{~h}$ before gold sputter-coating. Electron micrographs were taken using a Hitachi S-450 scanning electron microscope. Data were analyzed as a general linear model.

Germination of $S$. secundiflora seed was influenced by sulfuric acid treatment and year of collection. All seeds treated with sulfuric acid germinated in 27 days, whereas only one control seed and only four hot-watertreated seeds germinated from the two seed lots. Mean number of days to germination decreased linearly $\left(R^{2}=0.86\right)$ as acid treatment period increased from 30 to $120 \mathrm{~min}$
(Table 1). Seeds collected from the 1987 crop germinated an average of 2 days earlier than seeds collected in 1988. After 27 days, seeds that had not germinated in the control and hot-water treatments were treated with sulfuric acid for $60 \mathrm{~min}$. More than $90 \%$ of these seeds germinated within 5 days, indicating continued seed viability.

Initial seed length and width were influenced by year of seed collection. Initial seed size was not correlated with initial seed weight. Final seed length and seed width increased for the sulfuric acid-treated samples but not for the controls or the hot-water-treated group (data not shown). Germination was not correlated $(r<0.4)$ with initial or final seed size or weight change due to imbibition.

Anatomical features of papilionaceous testa include a cuticle, an epidermal, and a hypodermal layer (Fig. 1A) (Gum, 1981; Pohill, 1976). The cuticle is made of cutin, a waxy, fatty hemicellulose or pectinaceous outer layer of the seed testa. The epidermal layer consists of macrosclereid cells, the Malpighian cells that usually are elongated, thick-walled, and approximately hexagonal when viewed in transection. The hypodermal layer consists of irregularly shaped osteosclereid cells that are usually separated by intercellular spaces.

In some species of the Leguminosae, the waxy cuticle may interfere with the uptake of water, thereby limiting germination due to a coat-imposed dormancy (Bewley and Black, 1985). Seeds treated with hot water showed some loss of cuticular material. Research with 'Penngift' crownvetch seed has shown that $1 \mathrm{~min}$ in boiling water caused enough thermal expansion to rupture the seedcoat and separate the Malpighian cells, allowing water to penetrate into the seed (Brant et al., 1971). No such rupturing of the epidermal layer following the hot-water soak treatment was seen in this study.

Treatment of seeds for $30 \mathrm{~min}$ with sulfuric acid resulted in removal of the cuticular layer in a majority of the seed and in visibility of the Malpighian layer (Fig. 1B). Higher magnification $(\times 1240)$ indicated cracks in the outer portion of the epidermal layer. When seeds were treated with acid for 60 or 120 rein, the cuticular layer was completely removed (Fig. 1C). The 60- and 120-

Table 1. The influence of acid $\left(\mathrm{H}_{2} \mathrm{SO}_{4}\right)$ scarification treatments and seed collection year (1987) and 1988) on the germination of Sophora secundiflora seeds.

\begin{tabular}{lc}
\hline \hline Criteria & Days to $50 \%$ germination \\
\hline Duration of acid & \\
treatment (min) & \\
30 & \\
60 & 8.3 \\
120 & 6.2 \\
Yeary & 4.9 \\
1987 & \\
1988 & 5.3 \\
\hline
\end{tabular}

${ }^{\mathrm{z}}$ Significant linear response $[\mathrm{Pr}>\mathrm{F}=0.0001$, $\left.R^{2}=0.86, \mathrm{y}=13.45-17.1(\mathrm{x})\right]$. The control and hot-water treatments were not included due to germination of $<5 \%$.

yMeans significantly different at $P=0.05$. 

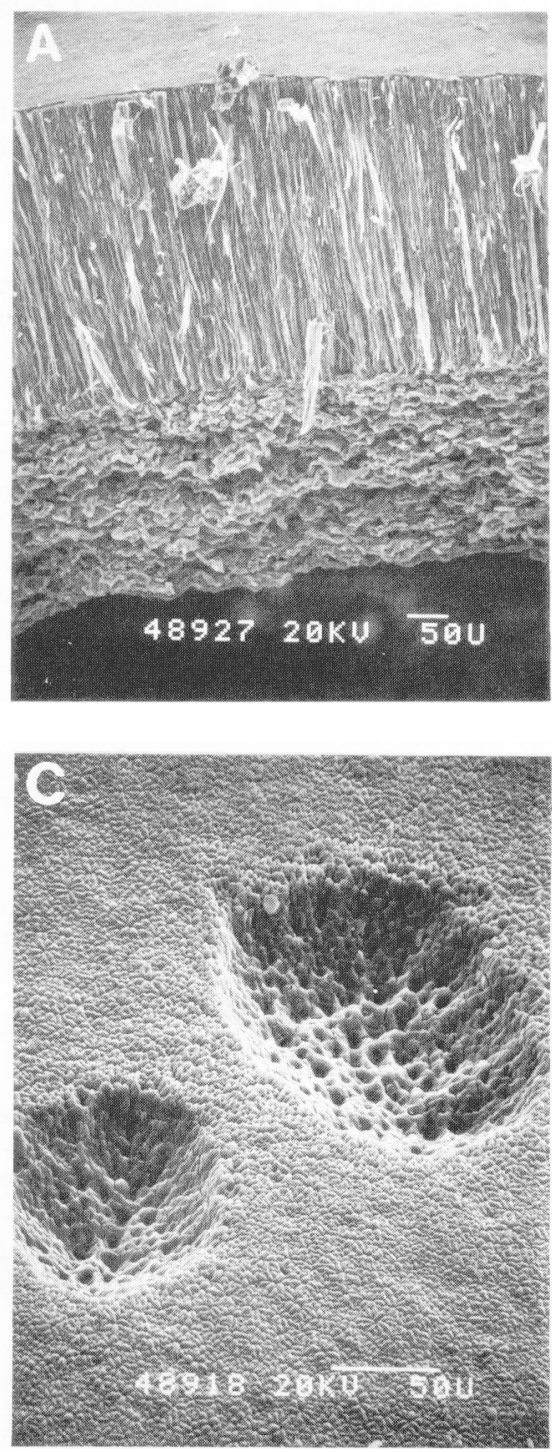

Fig. 1. (A) Cross section of Sophora secundiflora testa; cuticle, epidermal, and hypodermal layers (thickness 350 and 230um, respectively). (B) 30-min sulfuric acid treatment; some cuticle remains; tops of Malpighian cells are visible. $(\times 236)$ (C) 60-min sulfuric acid treatment; note lack of cuticle and pitting of Malpighian cell layer. $(\times 236)$ (D) 120-min sulfuric acid treatment: note pitting of individual Malpighian cells. $(\times 1240)$

min acid treatments resulted in localized deep etching of the epidermal layer. These same treatments appeared to dissolve the tops of the Malpighian cells and also caused cracks in the epidermal layer (Fig. ID).

The hilum of certain leguminous seeds has also been implicated in prevention of germination (Gunn, 1981). Typical of papilionoid seeds, $\boldsymbol{S}$. secundiflora has a separation in the palisade layer known as the hilar groove (Fig. 2A). The hilar groove has been proposed to act as a hydroscopic valve permitting the loss of water from inside the seed when the seed is in a low-humidity environment. Acid treatment for $60 \mathrm{~min}$ removed all surface residue from the hilum, and numerous cracks and pitting were seen (Fig. 2B).

Previous research suggested that the impermeability of crownvetch seed was due to Malpighian cell layer caps (Brant et al., 1971). The cuticle and the hypodermal osteosclereid layer have also been implicated in the inter-
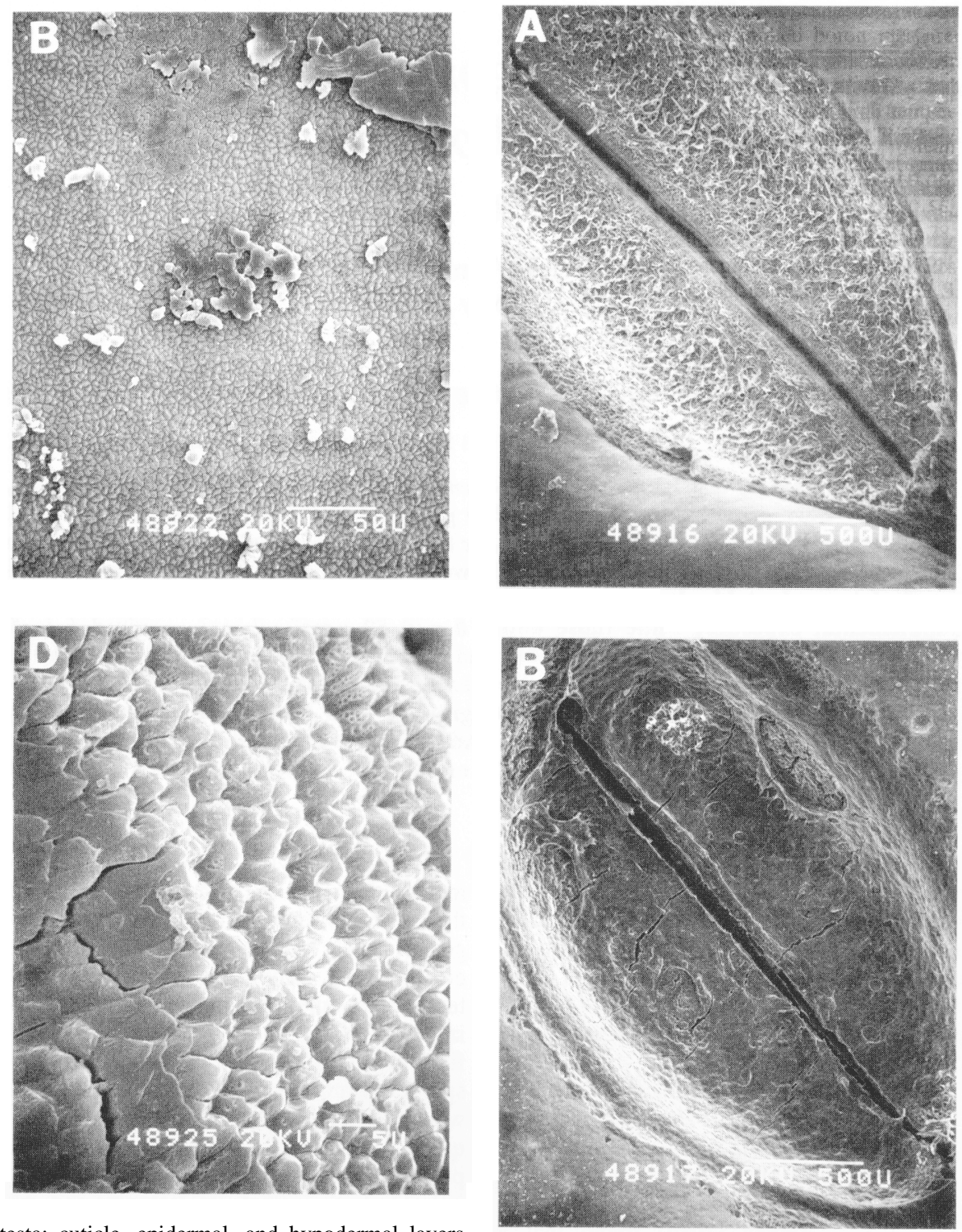

Fig. 2. Hilar region of Sophora secundiflora seeds. (A) Control seed; note hilar groove and smooth cuticle. $(\times 29)$ (B) Seed treated for 60 min with sulfuric acid; notice cracks and pitting in hilar region. $(\times 29)$

ference of water uptake in leguminous seed (Bewley and Black, 1985). SEM observations in our study showed that partial removal of the cuticular layer was necessary before germination occurred. Hot-water treatment was not sufficient to remove the cuticular layer and resulted in poor germination. When seeds were treated with sulfuric acid, some or all of the cuticular layer was removed. It is therefore evident that the cuticular layer in $S$. secundiflora can prevent germination by preventing the imbibition of water. However, it cannot be determined from this study whether scarification of the hypodermal layer was required for germination of $S$. secundiflora seed.

\section{Literature Cited}

Allan, H.H. 1961. Flora of New Zealand. vol. 1. R.E. Owen, Government Printer, Wellington, New Zealand.
Bewley, J.D. and M. Black. 1985. Seeds: Physiology of development and germination. Plenum Press, New York.

Brant, R. E., G.W. McKee, and R.W. Cleveland. 1971. Effect of chemical and physical treatment on hard seed of Penngift crownvetch. Crop Sci. 11:1-6.

Froberg, C.A. 1985. Tissue culture propagation of Sophora secundiflora. Proc. Intl. Plant Prop. Soc. 35:750-754

Gunn, C.R. 1981. Seeds of Leguminosae, p. 913925. In: R.M. Pohill. and P.H. Raven (eds.). Advances in legume systematic. England Ministry of Agriculture, Fisheries, and Food, London.

Pohill, R.M. 1976. Genisteae (Adanson) Bentham and related tribes (Leguminosae). Bet. Systematic 1:143-368.

Smith, G.C. and K. Pittcock. 1989. The collector's quest. Amer. Nurseryman 169(1):56-65.

Wyman, D. 1953. Seeds of woody plants. Arnoldia 13:41-60. 